\title{
The Influence of Fish Oil on Neurological Development and Function
}

\author{
Noran M. Abu-Ouf, Mohammed M. Jan
}

\begin{abstract}
Fish oil originates from fish tissue rich in omega-3 fatty acids. These include eicosapentaenoic acid (EPA), and docosahexaenoic acid (DHA). Healthy individuals are advised to consume foods rich in fish oil at least twice a week. However, such intake varies depending on cultural or personal preference, and socio-economic status. Many families and patients with chronic neurological conditions consume supplements containing omega-3 fatty acids. We are frequently requested to give advice and recommendations on using such agents to help improve neurological developmental and cognitive functions. The objective of this review is to discuss the available literature supporting the role of fish oils on brain development and function. There is a growing body of literature suggesting a potential benefit of long chain polyunsaturated fatty acids; however it is still unclear if there are response variations according to the developmental stage, age, and dose.
\end{abstract}

\begin{abstract}
RÉSUMÉ: L'influence de l'huile de poisson sur le développement et la fonction neurologique. L'huile de poisson provient de tissus de poisson riches en acides gras oméga-3, l'acide eicosapentaénol̈que (EPA) et l'acide docosahexaénoïque (DHA). On conseille aux individus en bonne santé de consommer des aliments riches en huiles de poisson au moins deux fois par semaine. Cependant, leur consommation varie selon les préférences culturelles ou personnelles ainsi que selon le statut socio-économique. Plusieurs familles et plusieurs patients atteints de maladies neurologiques chroniques consomment des suppléments contenant des acides gras oméga-3. On nous demande souvent des conseils et des recommandations sur l'utilisation de ces agents pour aider à améliorer le développement neurologique et les fonctions cognitives. L'objectif de cette revue est de discuter de la littérature disponible en faveur du rôle des huiles de poisson dans le développement et le fonctionnement du cerveau. Il existe une documentation de plus en plus importante qui suggère que les acides gras polyinsaturés à longue chaîne pourraient être bénéfiques. Cependant, on ne sait pas si la réponse peut varier selon le stade du développement, l'âge et la dose.
\end{abstract}

Can J Neurol Sci. 2014; 41: 13-18

Fish oil originates from oil rich fish tissue that contains omega-3 fatty acids. These include eicosapentaenoic acid (EPA), and docosahexaenoic acid (DHA), both of which are eicosanoids precursors ${ }^{1}$. Omega- 3 fatty acid from food is metabolized by desaturation using desaturase enzymes ${ }^{2}$. The American Heart Association's guidelines recommends that healthy individuals should consume foods rich in fish oil at least twice a week (Table 1). However, such intake varies depending on cultural or personal preference, seasonality, availability, and socioeconomic status ${ }^{2}$. In addition, the requirement should be further increased to at least $1 \mathrm{gm} /$ day of EPA and DHA for those with history of ischemic heart disease ${ }^{3}$. In our practice, many families and patients with chronic neurological conditions consume supplements containing omega- 3 fatty acids. We are frequently requested to give advice and recommendations on using such agents to help improve neurological developmental and cognitive functions. Therefore, in this review we aim to discuss the available literature supporting the role of fish oils on brain development and function.

\section{Fish Oil and Brain Development}

Neurogenesis is followed by migration, organization, and myelination ${ }^{4}$. Various stages of normal brain development and associated disorders are summarized in Table 2. Most structural brain development occurs before birth, however, organization and myelination continue for several years after delivery ${ }^{4}$. These normal developmental stages are all contingent on a variety of growth factors, hormones, certain proteins and nutrients whose role is to initiate and guide this process. Myelin in particular is heavily composed of lipids and fatty acids. Therefore, fatty acid intake is needed for optimal myelination and brain organization and development. Most brain growth after delivery is the result

\footnotetext{
From the Department of Pediatrics, Faculty of Medicine, King Abdulaziz University, Jeddah, Kingdom of Saudi Arabia.

Received June 13, 2013. Final Revisions Submitted August 29, 2013. Correspondence to: Mohammed M.S. Jan, Department of Pediatrics, Faculty of Medicine, King Abdulaziz University, PO Box 80215, Jeddah 21589, Kingdom of Saudi Arabia.Email: mmjan@kau.edu.sa.
} 


\section{Table 1: List of food sources rich in omega 3 fatty acids}

Tuna
Pollock
Salmon
Cod
Catfish
Flounder
Grouper
Halibut
Mahi mahi
Orange roughy
Red snapper
Shark
Swordfish
Tilefish
King mackerel

of relatively fast myelination which is reflected on fast neurological development during the first years of life. Studies have found that an adult brain is half as active as in a three yearold child ${ }^{5}$. Both nutrition and psychosocial interaction are vital for ongoing cognitive, language, and social neurological "functional" development.

\section{Fish Oil and Brain Transport}

Several authors have proposed theories for the sophisticated delivery of essential polyunsaturated fatty acids (PUFA) from the blood into the brain ${ }^{6-10}$. They argued that the essential role of the blood brain barrier ( $\mathrm{BBB})$ in controlling this process is dependent on the stage of human development and chronological age. The structure and function of the BBB evolves with age, however, most studies did not determine the alterations in the rate of transfer of PUFA into the brain as people age ${ }^{7,8}$. It is therefore possible that omega-3 fatty acids have a varying speed of transport into the brain. The brain also has the ability to transform linoleic and alpha-linolenic acids into lengthier chain fatty acids, such as arachidonic acid (AA) and docosahexaenoic acid (DHA) $)^{7,8}$. However, there is evidence that the developing brain may be less able to carry out such conversion processes, particularly in infancy 9,10 .

\section{Fish Oils and Brain Structure}

In addition to the impact of PUFA on brain-mediated functions, there is also an impact on aspects of brain structure. Fatty acids and lipids are important structural components of cerebral white matter ${ }^{11}$. They are incorporated in the formation of neuronal membranes and axonal myelin sheaths. Lipids constitute around $50 \%$ of the neuronal membrane structure, which is also composed of proteins ${ }^{12}$. However, lipids make up around $70 \%$ of the myelin sheaths. Whilst the protein element is particularly resilient and resistant to change, the lipid element is altered regularly ${ }^{12-14}$. The neuronal membrane fluidity index may therefore change, depending on the impact of PUFA resulting in some functional alterations. It has been found that some molecules within the membrane can be physically altered as a result of this fluidity ${ }^{15}$. In vitro studies revealed that the membrane can be converted into liquid by alcohol, while cholesterol toughens its texture ${ }^{15}$. However, it is not entirely clear whether alterations in the lipid element of the membrane would result in significant variations in neuronal functions. Secondly, the impact of fatty acid supplementation on the makeup and the function of the neuronal membrane need to be confirmed. Preliminary studies have suggested some alterations in both the structure and function of the membrane ${ }^{16}$. Improving the integrity and function of the myelin sheaths will theoretically result in better axonal function ${ }^{17}$. Poor myelination will result in deterioration in neuronal connectivity and therefore variations in neurological functions ${ }^{18}$. This was highlighted further in another study that examined the effects of fatty acids obtained from the diet on the healthy function of myelin ${ }^{19}$. The results showed a benefit of supplementing formulas for premature infants with

Table 2: Stages of normal brain development and associated disorders

\begin{tabular}{|l|l|l|}
\hline STAGE & PEAK TIMING & DISORDER \\
\hline Primary neurulation & $3-4$ weeks of gestation & Neural tube defects \\
\hline Prosencephalic development & $2-3$ months of gestation & $\begin{array}{l}\text { Holoprosencephaly } \\
\text { Agenesis of corpus callosum }\end{array}$ \\
\hline Neuronal proliferation & $3-4$ months of gestation & $\begin{array}{l}\text { Micrencephaly } \\
\text { Megalencephaly }\end{array}$ \\
\hline Neuronal migration & $3-5$ months of gestation & $\begin{array}{l}\text { Lissencephaly } \\
\text { Band heterotopia }\end{array}$ \\
\hline Organization & 5 months and onward & $\begin{array}{l}\text { Schizencephaly } \\
\text { Polymicrogyria }\end{array}$ \\
\hline Myelination & Term and onward & \begin{tabular}{l} 
Hypomyelination \\
\hline
\end{tabular} \\
\hline
\end{tabular}


Table 3: Studies on the cognitive effects of long chain polyunsaturated fatty acids supplementation in healthy term infants

\begin{tabular}{|c|c|c|c|c|c|c|c|}
\hline Authors & Type & Place & Sample & Duration & Intervention & Measurement & Outcome \\
\hline $\begin{array}{l}\text { Auestad et } \\
\text { al, } 2001\end{array}$ & RCT & USA & 404 & 1 year & $\begin{array}{l}\text { DHA }(0.14 \%) \text { and } \\
\text { AA }(0.45 \%)\end{array}$ & $\begin{array}{l}\text { Bayley scale of infant } \\
\text { development and infant } \\
\text { behavior questionnaire }\end{array}$ & None \\
\hline $\begin{array}{l}\text { Unay et al, } \\
2004\end{array}$ & RCT & Turkey & 80 & 16 weeks & DHA $(0.55 \%)$ & $\begin{array}{l}\text { Brainstem auditory evoked } \\
\text { response }\end{array}$ & $\begin{array}{l}\text { Quicker development } \\
\text { of BAEP }\end{array}$ \\
\hline $\begin{array}{l}\text { Willatts et al, } \\
1998\end{array}$ & RCT & UK & 44 & 4 months & LCPUFA & Problem solving testing & $\begin{array}{l}\text { Enhanced intentional } \\
\text { solutions }\end{array}$ \\
\hline $\begin{array}{l}\text { Fang et al, } \\
2005\end{array}$ & RCT & Taiwan & 27 & 6 months & $\begin{array}{l}\text { DHA }(0.05 \%) \text { and } \\
\operatorname{AA}(0.10 \%)\end{array}$ & $\begin{array}{l}\text { Bayley scale of infant } \\
\text { development }\end{array}$ & $\begin{array}{l}\text { Significant positive } \\
\text { effects }\end{array}$ \\
\hline $\begin{array}{l}\text { Bouwstra et } \\
\text { al, } 2005\end{array}$ & RCT & Holland & 472 & 2 months & $\begin{array}{l}\text { AA }(0.38 \%) \\
\text { DHA }(0.23 \%) \\
\text { GLA }(0.18 \%)\end{array}$ & $\begin{array}{l}\text { Quality of general movement } \\
\text { (QGM), and auditory } \\
\text { brainstem evoked potential }\end{array}$ & $\begin{array}{l}\text { Improved QGM, no } \\
\text { effect on the BAEP }\end{array}$ \\
\hline
\end{tabular}

RCT=randomized controlled trial; GLA=gamma linolenic acid; BAEP=brainstem auditory evoked potential; DHA=docosahexaenoic acid; AA=arachidonic acid; LCPUFA=long-chain polyunsaturated fatty acid; QGM=quality of general movement

AA and DHA from the time of first enteral feeding to 12 monthsof-age on growth, visual acuity, and multiple indices of development ${ }^{19}$. However, the overall evidence is not convincing of an effect on function.

\section{Fish Oil and Cognitive Function}

There is a growing body of evidence indicating that long chain polyunsaturated fatty acids (LCPUFA) play a pivotal role in cognitive development (Table 3). Both docosahexaenoic acid (DHA) and arachidonic acid (AA) are important for cognitive function $^{20,21}$. These functions include memory, learning, reasoning, attention and language ${ }^{22}$. Studies documenting the positive cognitive effects in young infants are summarized in
Table 3. However, there is a dearth of randomized controlled trials examining the possible impact of fatty acids supplementation in children older than two years-of-age. A prospective Dutch cohort study evaluated the connection between DHA status at birth and subsequently at aged seven with cognitive function, and found no positive relationship ${ }^{23}$. Other authors examined the relationship between PUFA intake and psychosocial and cognitive performance of 6-16 year-old children in a cross-sectional analysis and concluded that a raised daily intake $(10 \mathrm{~g})$ was linked to improved performance on the digit span testing ${ }^{24}$. This did not extend to all cognitive function; and no significant relationship was found for block design, arithmetic, and reading comprehension tests. Therefore, fatty

Table 4: Studies on effects on visual acuity of long chain polyunsaturated fatty acids supplementation in healthy term infants

\begin{tabular}{l|l|l|l|l|l|l|l}
\hline Authors & Type & Place & Sample & Duration & Intervention & Measurement & Outcome \\
\hline $\begin{array}{l}\text { Birch et al, } \\
\mathbf{1 9 9 8}\end{array}$ & RCT & USA & 108 & 1 year & DHA and AA & $\begin{array}{l}\text { Visual evoke } \\
\text { potential (VEP) }\end{array}$ & $\begin{array}{l}\text { Positively associated with } \\
\text { brain and eye development }\end{array}$ \\
\hline $\begin{array}{l}\text { Hoffman } \\
\text { et al, 2000 }\end{array}$ & RCT & USA & 87 & 17 weeks & DHA and AA & VEP & $\begin{array}{l}\text { Positively associated with } \\
\text { improved later visual acuity }\end{array}$ \\
\hline $\begin{array}{l}\text { Birch et al, } \\
\mathbf{2 0 0 5}\end{array}$ & RCT & USA & 103 & 1 year & DHA and AA & VEP & $\begin{array}{l}\text { Positively associated with } \\
\text { improved later visual acuity }\end{array}$ \\
$\begin{array}{l}\text { Birch et al, } \\
\mathbf{2 0 0 6}\end{array}$ & RCT & USA & 79 & 17 weeks & DHA and AA & $\begin{array}{l}\text { Electronic Visual } \\
\text { Acuity (EVA) }\end{array}$ & $\begin{array}{l}\text { Positively associated with } \\
\text { improved later visual acuity }\end{array}$ \\
\hline $\begin{array}{l}\text { Auestad et } \\
\text { al, 2003 }\end{array}$ & RCT & USA & 276 & 1 year & DHA and AA & $\begin{array}{l}\text { Beery visual- } \\
\text { motor index } \\
\text { and acuity card } \\
\text { procedure }\end{array}$ & $\begin{array}{l}\text { No effect on } \\
\text { visual acuity }\end{array}$ \\
\hline
\end{tabular}

$\mathrm{RCT}=$ randomized controlled trial; $\mathrm{DHA}=$ docosahexaenoic acid; $\mathrm{AA}=$ arachidonic acid 
Table 5: Studies on the impact of long chain polyunsaturated fatty acids supplementation during pregnancy and lactation on term infants

\begin{tabular}{|c|c|c|c|c|c|c|c|}
\hline Authors & Type & Place & Sample & Duration & Intervention & Measurement & Outcome \\
\hline $\begin{array}{l}\text { Malcolm et } \\
\text { al, } 2003\end{array}$ & RCT & UK & 63 & $\begin{array}{l}15^{\text {th }} \text { gestational } \\
\text { weeks to delivery }\end{array}$ & DHA & $\begin{array}{l}\text { Visual evoked } \\
\text { potential (VEP) and } \\
\text { electroretinography }\end{array}$ & No effects \\
\hline $\begin{array}{l}\text { Tofail et al, } \\
2006\end{array}$ & RCT & Bangladesh & 249 & $\begin{array}{l}25^{\text {th }} \text { gestational } \\
\text { week to delivery }\end{array}$ & $\begin{array}{l}\text { DHA and } \\
\text { EPA }\end{array}$ & $\begin{array}{l}\text { Bayley scales of } \\
\text { infant development }\end{array}$ & No effects \\
\hline $\begin{array}{l}\text { Helland et al, } \\
2001\end{array}$ & RCT & Norway & 341 & $\begin{array}{l}19^{\text {th }} \text { gestational } \\
\text { week to } 3 \text { month } \\
\text { of age }\end{array}$ & $\begin{array}{l}\text { DHA, and } \\
\text { EPA }\end{array}$ & $\begin{array}{l}\text { EEG and fagen test of } \\
\text { intelligence }\end{array}$ & No effects \\
\hline $\begin{array}{l}\text { Helland et al, } \\
2003\end{array}$ & RCT & Norway & 90 & $\begin{array}{l}19^{\text {th }} \text { gestational } \\
\text { age to } 3 \text { month of } \\
\text { age }\end{array}$ & $\begin{array}{l}\text { DHA and } \\
\text { EPA }\end{array}$ & IQ & Higher IQ \\
\hline $\begin{array}{l}\text { Gibson et al, } \\
1997\end{array}$ & $\mathrm{RCT}$ & Australia & 52 & $\begin{array}{l}12 \text { weeks after } \\
\text { delivery }\end{array}$ & DHA & $\begin{array}{l}\text { VEP and Bayley } \\
\text { scales of infant } \\
\text { development }\end{array}$ & No effects \\
\hline $\begin{array}{l}\text { Lauritzen et } \\
\text { al, } 2004\end{array}$ & RCT & Denmark & 97 & $\begin{array}{l}16 \text { weeks after } \\
\text { delivery }\end{array}$ & $\begin{array}{l}\text { DHA, EPA, } \\
\text { and DPA }\end{array}$ & $\begin{array}{l}\text { Means end problem } \\
\text { solving (MPS) and } \\
\text { MacArthur } \\
\text { communicative } \\
\text { Development } \\
\text { Intervention ( MACI) }\end{array}$ & $\begin{array}{l}\text { Higher } \\
\text { MPS }\end{array}$ \\
\hline $\begin{array}{l}\text { Jensen et al, } \\
2005\end{array}$ & RCT & USA & 160 & $\begin{array}{l}4 \text { months after } \\
\text { delivery }\end{array}$ & DHA & $\begin{array}{l}\text { Bayley scales of } \\
\text { infant development } \\
\text { (BSID) }\end{array}$ & $\begin{array}{l}\text { Improved } \\
\text { BSID } \\
\text { scores }\end{array}$ \\
\hline
\end{tabular}

RCT=randomized controlled trial; EPA=eicosapentaenoic acid; $\mathrm{IQ}=$ intelligence quotien; DHA=docosahexaenoic acid;

acid supplementation may be advantageous for children's working memory during infancy but more data are needed to evaluate their positive effects on older children.

\section{Fish Oil and Visual Function}

Neonates have limited visual acuity which evolves slowly during the first year of life ${ }^{25}$. Therefore, this is a critical time where negative nutritional state can affect the development of the visual pathway from the retina and the visual cortex ${ }^{26}$. These areas have high concentrations of polyunsaturated fatty acids, particularly DHA, which heighten in the last trimester of the pregnancy and continue to increase during the first six post-natal months ${ }^{27}$. DHA is incorporated in the structural phospholipids of the retinal photoreceptors where it constitutes up to $50 \%$ of the total fatty acids ${ }^{28,29}$. Although DHA is present in breast milk, levels vary substantially depending on the mother's food intake $^{30,31}$. The level is significantly higher for mothers with increased fish intake. DHA has augmented a variety of infant formulas over the last 15 years, and a range of clinical trials have assessed infant formulas with and without supplemented DHA (Table 4). Randomized control trials consistently reflect a positive association between DHA supplementation and improved visual acuity despite variations in the outcome measurements (Table 4). Current infant formulas are supplemented by LCPUFA to ensure adequate supply for optimum developmental needs ${ }^{32}$.

\section{Fish Oil in Pregnancy and Lactation}

Trials that have examined the impact of supplementation of pregnant mothers on their infant's visual acuity and cognitive development are summarized in Table 5. Although some studies showed no benefit, others found improvements on visual and cognitive development. Three randomized controlled trials evaluated the impact of supplementing lactating mothers on the cognitive development of their children (Table 5). The positive effects were age related. For instance, one study found that the cognitive benefits at one year-of-age were not present when the children were two years old ${ }^{33}$. On the other hand, a Dutch study supplemented lactating mothers with fish oil and found positive effects with advancing infant's age on their visual and cognitive development ${ }^{34}$. Upon further follow-up, gender differences were uncovered with a higher impact on females. These findings suggest that longer periods of follow-up are needed to determine the outcome, keeping in mind the improved accuracy of various cognitive tests with advancing age ${ }^{34}$. Contradictory results may also result from smaller study samples. However, there is good evidence that there is some benefit of maternal supplementation to the neurological development of their infants (Table 5). Further research is clearly needed in this area to provide evidence based and clinically relevant recommendations.

\section{Dosing and Composition}

The dose, composition, and ratios of supplemented fatty acids vary according to the indication and targeted function ${ }^{35}$. A 1:1 
ratio of omega- 6 to omega-3 PUFA is the most advised in the prevention of cardiovascular diseases, while a $4: 1$ ratio is suggested for promoting brain functions ${ }^{36}$. This ratio is thought to positively affect the neuronal membrane and healthy functioning nervous system ${ }^{37-39}$. In addition, there is evidence that variations in ratio, to $6: 1$ for example, can have negative effects on the speed of development ${ }^{40,41}$. Thus, there is a growing consensus amongst researchers that the amount of PUFA, along with a 4:1 ratio are both significant to healthy brain development and function. However, the issue of whether or not to routinely augment infant formula with long chain PUFA is still to be determined ${ }^{42,43}$. It has become evident that the speed of myelin lipid turnover is dependent on age. As the person ages and the brain subsequently ages, the speed of turnover is hindered depending on the PUFA ratio, and so the ability to repair affected myelin is hampered and slowed ${ }^{44}$.

\section{Conclusions ANd Recommendations}

There is a growing body of literature suggesting a potential benefit of long chain polyunsaturated fatty acids in neurological development and function. While increasing consensus is developing regarding the administered supplementation, it is still unclear if there are response variations according to the developmental stage, age, and dose. This needs to be investigated further at different development stages to include infants and young children with longitudinal long term follow up. Studying neurologically impaired children in a randomized controlled manner is needed in order to validate reliably the positive effects of long chain polyunsaturated fatty acids on neurological development and function. More research is also required to determine the impact of supplementation on pregnant and lactating mothers. Standardization of the supplement in terms of composition and dosing, as well as, the outcome measures with larger sample size are needed to document and reliably reproduce their positive effects in a clinically relevant and scientific manner. Healthy varied diet and breast feeding for infants will ensure adequate intake of essential fatty acids. However, if this is not possible, DHA supplemented formulas are recommended. There is no consensus on the necessary quantities to support neurologically impaired children.

\section{REFERENCES}

1. Moghadasian MH. Advances in dietary enrichment with n-3 fatty acids. Crit Rev Food Sci Nutr. 2008;48(5):402-10.

2. Mahaffey KR. Fish and shellfish as dietary sources of methylmercury and the $\alpha-3$ fatty acids, eicosahexaenoic acid and docosahexaenoic acid:risks and benefits. Environ Res. 2004;95: 414-28.

3. Chan EJ, Cho L. What can we expect from omega-3 fatty acids? Cleve Clin J Med. 2009;76(4):245-51.

4. Isaacs, EB, Fischl BR, Quinn BT, Wui CK, Gadian DG, Lucas A. Impact of breast milk on intelligence quotient, brain size, and white matter development. Ped Res. 2010;67(4):357-62.

5. Johnson MH, Grossmann T, Kadosh KC. Mapping functional brain development: building a social brain through interactive specialization. Dev Psychol. 2009:45(1):151-9.

6. Taha AY, Trepanier MO, Ciobanu FA. A minimum of 3 months of dietary fish oil supplementation is required to raise amygdaloid after discharge seizure thresholds in rats--implications for treating complex partial seizures. Epilepsy Behav. 2013;27(1): 49-58.
7. Natalie Sinn, Milte C, Howe PR. Oiling the brain: a review of randomized controlled trials of omega- 3 fatty acids in psychopathology across the lifespan. Nutr. 2010;2:128-70.

8. Terracina L, Brunetti M, Avellini L, de Medio GE, Trovarelli G, Gaiti A. Linoleic acid metabolism in brain cortex of aged rats. Ital J Biochem. 1992;41:225-35.

9. Rapoport SI. In vivo fatty acid incorporation into brain phospholipids in relation to plasma availability, signal transduction and membrane remodeling. J Mol Neurosci. 2001; 16:243-61.

10. Su HM, Huang MC, Saad NM, Nathanielsz PW, Brenna JT. Fetal baboons convert $18: 3$ n-3 to $22: 6 n-3$ in vivo: a stable isotope tracer study. J Lipid Res. 2001;42:581-6.

11. McCann JC, Ames BN. Is docosahexaenoic acid, an n-3 long-chain polyunsaturated fatty acid, required for development of normal brain function? An overview of evidence from cognitive and behavioral tests in humans and animals. Am J Clin Nutr. 2005; 82:281-95.

12. Richardson UI, Wurtman RJ. Polyunsaturated fatty acids stimulate phosphatidylcholine synthesis in PC12 cells. Biochem Biophys Acta. 2007;1771:558-63.

13. Yu T, Lieberman AP. Npc1 acting in neurons and glia is essential for the formation and maintenance of CNS myelin. PLoS Genet. 2013;9(4):e1003462.

14. Yehuda S, Rabinovitz S, Carasso RL, Mostofsky DT. The role of PUFA in restoring the aging neuronal membrane. Neurobiol Aging. 2002;23:843-53.

15. Kothapalli KS, Anthony JC, Pan BS. Differential cerebral cortex transcriptomes of baboon neonates consuming moderate and high docosahexaenoic acid formulas. PLoS One. 2007;2:e370.

16. Calviello G, Su HM, Weylandt KH, Fasano E, Serini S, Cittadini A. Experimental evidence of -3 polyunsaturated fatty acid modulation of inflammatory cytokines and bioactive lipid mediators: their potential role in inflammatory, neurodegenerative, and neoplastic diseases. Biomed Res Int. 2013;7: 431-7.

17. Hussar CR, Pasternak T. Flexibility of sensory representations in prefrontal cortex depends on cell type. Neuron. 2009;64:730-43.

18. Salvati S, Attorri L, Avellino C, Di Biase A, Sanchez M. Diet, lipids and brain development. Dev Neurosci. 2000;22:481-7.

19. Auestad N. Infant nutrition - brain development - disease in later life. Dev Neurosci. 2000;22:472-3.

20. Agostoni C, Galli C, Riva F, Colombo C, Giovannini M, Marangoni F. Reduced docosahexaenoic acid synthesis may contribute to growth restriction in infants born to mothers who smoke. J Pediatr. 2005;147:854-6.

21. Yui K, Koshiba M, Nakamura S, Kobayashi Y. Effects of large doses of arachidonic acid added to docosahexaenoic acid on social impairment in individuals with autism spectrum disorders: a double-blind, placebo-controlled, randomized trial. J Clin Psychopharmacol. 2012;32(2):200-6.

22. Parletta N, Cooper P, Gent DN, Petkov J, O'Dea K. Effects of fish oil supplementation on learning and behaviour of children from Australian Indigenous remote community schools: a randomised controlled trial. Prostaglandins Leukot Essent Fatty Acids. 2013; 89(2-3):71-9.

23. Bakker EC, Ghys AJA, Kester ADM, et al. Long-chain polyunsaturated fatty acids at birth and cognitive function at $7 \mathrm{y}$ of age. Eur J Clin Nutr. 2003;57:89-95.

24. Zhang J, Hebert JR, Muldoon MF. Dietary fat intake is associated with psychosocial and cognitive functioning of school-aged children in the united states. J Nutr. 2005;135:1967-73.

25. San Giovanni JP, Berkey CS, Dwyer JT, Colditz GA. Dietary essential fatty acids, long-chain polyunsaturated fatty acids, and visual resolution acuity in healthy full term infants: a systematic review. Early Hum Dev. 2000:57:165-88.

26. Uauy R, Hoffman DR, Mena P, Llanos A, Birch EE. Term infant studies of DHA and ARA supplementation on neurodevelopment: results of randomized controlled trials. J Pediatr. 2003;143(4):17-25.

27. Innis SM. Metabolic programming of long-term outcomes due to fatty acid nutrition in early life. Matern Child Nutr. 2011;7(2): $112-23$. 
28. Hammond BR, Wooten BR. Comments on the use of raman spectroscopy for the in vivo measurement of human macular pigment. Appl Spectrosc. 2006;60(11):e1348-9.

29. Bernstein PS, Delori FC, Richer S, van Kuijk FJ, Wenzel AJ. The value of measurement of macular carotenoid pigment optical densities and distributions in age-related macular degeneration and other retinal disorders. Vision Res. 2010;50(7):716-28.

30. Yuhas R, Pramuk K, Lien EL. Human milk fatty acid composition from nine countries varies most in DHA. Lipids. 2006;41:851-8.

31. Brenna JT, Varamini BA, Boetacher JA, Arterburn LM. Docosahexaenoic and arachidonic acid concentrations in human breast milk worldwide. Am J Clin Nutr. 2009:85:1457-64.

32. Weiler H, Fitzpatrick-Wong S, Schellenberg J, McCloy U, Veitch R, Kovacs H. Maternal and cord blood long chain polyunsaturated fatty acids are predictive of bone mass at birth in healthy termborn infants. Ped Res. 2005;58:1254-8.

33. Gibson RA, Neumann MA, Makrides M. Effect of increasing breast milk docosahexaenoic acid on plasma and erythrocyte phospholipid fatty acids and neural indices of exclusively breast fed infants. Eur J Clin Nutr. 1997:54:578-84.

34. Lauritzen L, Jorgensen MH, Mikkelsen TB, et al. Maternal fish oil supplementation in lactation: effect on visual acuity and n-3 fatty acid content of infant erythrocytes. Lipids. 2004;39(3):195-206.

35. Schlotz W, Phillips DI. Fetal origins of mental health: evidence and mechanisms. Brain Behav Immun. 2009;23:905-16.

36. Kaur N, Chugh V, Gupta AK. Essential fatty acids as functional components of foods - a review. J Food Sci Tech. 2012;10(1): 677-9.

37. Yehuda S, Carasso RL, Mostofsky DI. Essential fatty acid preparation (1:4 ratio) rehabilitates learning deficits induced by AF64A and 5,7-DHT. Neuro Report. 1995;6:511-15.
38. Auestad N, Scot DT, Janowsky JS, Jacobsen C, Carroll RE, Montalto MB. Visual, cognitive, and language assessments at 39 months: a follow-up study of children fed formulas containing long-chain polyunsaturated fatty acids to 1 year of age. Pediatr. 2003; $112: \mathrm{e} 177-83$

39. Wan, JM Huang L, Rong R, Tan R, Wang J, Kang JX. Endrogenously decreasing tissue n-6/n-3 fatty acid ratio reduces atherosclerotic lesions in Apolipoprotein E-deficient mice by inhibiting systemic and vascular inflammation. Arter Throm Vasc Biol. 2010:30:2487-94.

40. Jumpsen J, Lien EL, Goh YK, Clandinin MT. Small changes of dietary (n-6) and (n-3)/fatty acid content ratio alter phosphatidylethanolamine and phosphatidylcholine fatty acid composition during development of neuronal and glial cells in rats. J Nutr. 1997;127:724-31.

41. Jumpsen JA, Lien EL, Goh YK, Clandinin MT. During neuronal and glial cell development diet n-6 to n-3 fatty acid ratio alters the fatty acid composition of phosphatidylinositol and phosphatidylserine. Biochim Biophys Acta. 1997;1347:40-50.

42. Wainwright PE, Xing HC, Mutsaers L, McCutcheon D, Kyle D. Arachidonic acid offsets the effects on mouse brain and behavior of a diet with a low (n-6):(n-3) ratio and very high levels of docosahexaenoic acid. J Nutr. 1997;127:184-93.

43. Stockard JE, Saste MD, Benford VJ, Barness L, Auestad N, Carver JD. Effect of docosahexaenoic acid content of maternal diet on auditory brainstem conduction times in rat pups. Dev Neurosci. 2002;22:494-9.

44. Ando S, Tanaka Y, Toyoda Y, Kon K. Turnover of myelin lipids in aging brain. Neurochem Res. 2003;28:5-13. 